\title{
THE FUTURE OF THE EUROPEAN UNION: TOWARDS A FUNCTIONAL FEDERALISM
}

\author{
Marek DABROWSKI
}

The series of adverse shocks of both economic and political character that Europe has suffered since 2008, the last of them coming from the Brexit referendum, revealed numerous institutional gaps and asymmetries in the EU integration architecture. They originate from the voluntary nature of the EU project and the necessity to obtain unanimous approval of all member states to take new integration steps. To increase the resilience of the EU project against current and future shocks, its major institutional gaps and asymmetries should be addressed as quickly as possible. In this paper, we use the theory of fiscal federalism and subsidiarity principle to set the agenda of the EU reform. This includes the identification of areas such as completing the EMU and Schengen projects, foreign, security, and defence policies, environmental and climate change policies where further integration can offer substantial returns to scale and better provisions of global and pan-European public goods. On the other hand, there are also areas such as agriculture policy, products, services and labour standards, and fiscal surveillance rules, where deregulation in favour of market forces could ease business environment and make EU regulations less bureaucratic. Developing integration beyond the traditional economic sphere will also have an impact on the size of the EU budget, balance of power between the EU governing bodies (a bigger role of the European Parliament) and the democratic legitimacy of the EU project.

Keywords: European integration, European Union, theory of fiscal federalism, subsidiarity principle, EU budget, democratic legitimacy

JEL classification indices: F15, F55, H77

Marek Dabrowski, Non-Resident Fellow at Bruegel, Brussels; Professor at Higher School of Economics, Moscow; Fellow at CASE - Center for Social and Economic Research, Warsaw.

E-mail: marek.dabrowski@case-research.eu 


\section{INTRODUCTION}

Just after the $50^{\text {th }}$ anniversary of its existence (2007), the European Union (EU), the successor of the European Economic Community (EEC), has started to suffer from multiple shocks. Each of them has exposed serious weaknesses in the EU integration architecture.

The first shock came with the global financial crisis (GFC) of 2007-2009 and caused heavy GDP and employment losses, large fiscal costs, numerous incidences of beggar-thy-neighbour policies or hidden protectionism within the EU, and demonstrated weak fiscal discipline on national level. In 2010, it was followed by the European financial crisis (EFC), which hit the euro area periphery, in first instance, Greece. For a while, this crisis challenged the integrity of the euro zone, at least Greece's membership in this project. Fortunately, the so-called Grexit has not happened and, most likely, will not happen.

In summer 2015, the EU started to receive a great influx of refugees from the Middle East and North Africa (MENA) (Vimont 2016). Shortly afterwards, a wave of terrorist attacks organised by the Islamic State of Iraq and Syria (ISIS) hit several European cities such as Paris, Brussels, and Nice. Both exposed serious weaknesses in the EU's Common Foreign and Security Policy (CFSP), the institutional and policy architecture of the Schengen border-free area, and common justice and home affairs (JHA) policy. They also led to an increasing wave of nationalism and xenophobia (especially islamophobia) across the EU, with serious negative consequences for internal political cohesion and solidarity within the block. Although the influx of refugees slowed down as a result of the EUTurkey agreement in March 2016 (European Commission 2016), its root causes remained unaddressed.

Finally, the Brexit referendum on June 23, 2016, largely the product of internal British politics, but also influenced by the above-mentioned crises, has generated a huge political shock both to the UK and entire Europe, with potentially serious economic consequences for both entities. The magnitude of this shock will depend on the exact Brexit scenario (unknown yet in September 2016), the eventual depth of the economic and political disintegration between the UK and EU-27, and the political ability of the EU-27 to compensate for the loss of the second largest national economy, through the continuation of the integration project, including further EU enlargement in Eastern and South-Eastern Europe, and the improvement of the EU institutional architecture.

For sure, EU-27 will be smaller and weaker than EU-28 both in economic and geopolitical terms. The share of the EU in world's population will go down from 7.0 to $6.1 \%$, in global GDP at purchasing power parity terms - from 17.0 to $14.6 \%$, in global GDP at current international dollars - from 23.8 to $20.0 \%$, and 
in world's exports of goods and services at current prices and exchange rates from 33.9 to $30.3 \% .^{1}$

Even bigger losses will affect the EU's shares in the global financial market where the City of London plays a dominant role. The UK is also an important corporate governance centre (headquarter of many transnational corporations), centre of research and innovations, and the country of origin of many high-quality EU civil servants. Excellent British universities offer education to students from the entire European continent and the world.

Finally, the UK has a prominent position in a global decision-making process - as a permanent member of the United Nation's Security Council (one of the two EU member states), G7 (one of the four EU member states), G20 (one of the four EU member states), of the International Monetary Fund and World Bank (4.11\% of the voting power and one of 24 Executive Director positions), and of the Financial Stability Board (one of the six EU member states).

In this context, one may speculate whether the exit of the traditionally Eurosceptical UK will make further integration steps within the EU-27 politically easier (De Grauwe 2016) or, on the contrary, whether it will trigger disintegration sentiments in other member states (Grabbe - Lehne 2016). However, we are not going to follow this sort of reasoning because guessing future political trends is always intellectually risky and rather fruitless. Instead, we will try to conduct a diagnosis of the major weaknesses and gaps of the European integration architecture that has developed gradually since signing the Rome Treaty in 1957 and propose their improvements based on the theory of fiscal federalism and subsidiarity principle.

The paper starts with a brief analysis of historical origins of the current EU architecture (Section 2), followed by a discussion of major institutional asymmetries and variable geometry resulting from the voluntary character of the EU integration process (Section 3). In Section 4, we employ the theory of fiscal federalism and subsidiarity principle to outline directions of changes in EU integration architecture. Section 5 is devoted to the EU budget and Section 6 to the role of fiscal discipline mechanisms. In Section 7, we discuss consequences of changes in EU mandates and the EU budget for the EU institutional setup, with a focus on strengthening EU democratic legitimacy and forming the pan-European political space. Section 8 summarises the discussion and presents its conclusions.

World Bank's World Development Indicators 2014, http://databank.worldbank.org/data/ reports.aspx? source=world-development-indicators\# 


\section{HISTORICAL ORIGINS OF THE CURRENT ARCHITECTURE}

The European integration process does not have any historical precedents in history due to its voluntary character based on democratic procedures. That is, delegation of national sovereignty to the EU governing bodies has to be approved by either democratically elected parliaments or referenda in member states (MS). Most other federations and confederations, historical or contemporary, were created, at least partly, as a result of wars, conquests, colonisation, or other means of coercion. This includes the US, ${ }^{2}$ which often serves as a comparison or benchmark in analyses of various aspects of European integration.

The original political aim of the European project was to put a stop, once and for all, to the dramatic experience of many centuries of bloody conflicts in Europe, which culminated in two world wars in the $20^{\text {th }}$ century, and to build the economic foundations for peace and prosperity on the continent. It was to be accomplished by eliminating cross-country barriers to trade, capital movement, and the movement of people, adopting common legislation, and building joint institutions to make the single economic space.

Institutionally, the European integration process started with the signing of the European Coal and Steel Community (ECSC) Treaty in Paris in 1951, ${ }^{3}$ followed by the Rome Treaty in 1957, which created the EEC of six Western European countries (Belgium, France, Germany, Italy, Luxembourg, and the Netherlands). ${ }^{4}$ Seven subsequent rounds of EEC/EU enlargements brought the accession of:

- Denmark, Ireland, and the UK in 1973,

- Greece in 1981,

- Portugal and Spain in 1986,

- Austria, Finland, and Sweden in 1995,

- Cyprus, the Czech Republic, Estonia, Hungary, Latvia, Lithuania, Malta, Poland, Slovakia, and Slovenia in 2004,

- Bulgaria and Romania in 2007, and

- Croatia in 2013.

The voluntary character of EU membership and the necessity to obtain the unanimous endorsement of incumbents to join the "club" by a new applicant means that

2 Think about the role of the Mexican-American War of 1846-1848, the American Civil War of 1861-1865, or the colonisation of the territories belonging to Native Americans in building the US federation in its current institutional framework and geographic borders.

3 http://europa.eu/legislation_summaries/institutional_affairs/treaties/treaties_ecsc_en.htm

4 http://europa.eu/legislation_summaries/institutional_affairs/treaties/treaties_eec_en.htm 
(i) no country is forced to join the EU; (ii) the EU accession process, especially in the case of the less developed countries of Eastern and Southern Europe, was always long and involved a lot of conditionality; (iii) the EU candidates often faced the strong reservations of incumbents (the example of Turkey); and (iv) the EU is a special sort of "empire", which is far from ambitions to expand territorially.

In parallel to enlargement, the process of gradual integration deepening has also taken place. Major milestones involved:

- launching the EEC customs union (1968),

- the Single European Act (1986), which opened the door to the Single European Market (SEM),

- the Maastricht Treaty (1992), with the Economic and Monetary Union (EMU), CFSP, and renaming EEC into the EU,

- the Amsterdam Treaty (1997), which incorporated the Schengen Agreement of 1985, expanded co-operation in JHA, and increased prerogatives of the European Parliament, and

- the Lisbon Treaty (2007) that, among others, increased the number of issues decided by qualified majority voting (QMV) instead of unanimity and the competences of the European Parliament, reformed EU institutions, and adopted the Charter of Fundamental Rights of the EU.

As a result of these subsequent integration steps, by mid-2016 (i.e., still with the UK) all $28 \mathrm{EU}$ member states belonged to the customs union and SEM, in which most (but not all ${ }^{6}$ ) formal and informal barriers to free movement of goods, services, people, and capital were removed. In addition, 19 member states shared the common currency (euro) and 22 member states plus 4 non-member states formed a free-travel Schengen area without internal border controls. Decisions related to external trade, competition policy, regulations affecting SEM, monetary policy (in the case of euro zone members), some fiscal and other macroeconomic policies, customs, part of indirect taxation, research, energy, environment, transportation, etc., were transferred to the competencies of EU governing bodies. Beyond trade and economic issues, questions such as immigration and asylum, visas, common border management, justice and home affairs, and foreign and security policy were subject to coordination and common decisions within the EU, even if integration in those policy areas is not as deep as in the case of economic policy.

5 This is the important argument against the accusations of Russian government propaganda since 2014, suggesting that the EU wants to expand eastwards, forcing countries such as Ukraine or Moldova to join the block.

6 The process of building SEM remains unfinished in respect to some segments of financial, transportation and communication services, energy supply, government procurement, etc. (see Section 4.3). 


\section{INSTITUTIONAL ASYMMETRIES AND VARIABLE GEOMETRY}

The voluntary character of European integration means that each Treaty revision aiming to either delegate new prerogatives to the EU level or bring new countries to the "club" requires the unanimous agreement of all MS. This is often difficult to achieve. Thus, it should not be surprising that, from the historical perspective, the European integration process progressed slowly, step-by-step, often as a result of economic and political shocks, which delivered arguments for pooling resources and common decision making on the EU level. The Banking Union as a result of the EFC and recent initiatives to form the European Border and Coast Guard (EBCG) as a result of the refugee crisis of 2015-2016 are the best examples of emergency-inspired integration.

As a result, the EU represents a hybrid construction with many institutional asymmetries. It does not fall under any simple definition such as a federation, confederation, or international organisation. Integration progressed relatively far in the common external trade policy, building the customs union and SEM, even if the latter is not complete yet (see Section 4.3). The common currency and the Schengen area also represent examples of far-going integration initiatives (assuming the de facto federal character of the EU), but they remain evidently incomplete as revealed by the respective crises in the decade of 2010s. Furthermore, there is no conceptual consensus yet, at least in the case of the EMU (see Dabrowski 2015b), which additional integration steps are required to complete them.

In the political field, the integration process has not advanced equally far, even if one takes into account the provisions of the Lisbon Treaty. Slower political integration is reflected, among others, in the limited size of the EU budget (below $1 \%$ of gross national income (GNI)) and reluctance of MSs to transfer more financial resources to the EU level, even in the case of emergency, as has been experienced during the crises since 2008.

The limited EU competences and unanimity requirement in taking CFSP decisions by the Foreign Affairs Council diminishes the EU's geopolitical role and restricts its capacities to respond to numerous security crises in its neighbourhood (MENA, and the former Soviet Union (FSU)) which intensified in the decade of 2010s.

Along with the above-mentioned fundamental asymmetries in the EU institutional and policy architecture, the consensual character of integration process (often requiring compromises) has led to the phenomenon of "variable geometry", meaning that the degree of participation in the common integration projects differs between individual MSs. To be able to move forward and secure unanimity,

It is often referred to as 'multi-speed Europe' (see http://eur-lex.europa.eu/summary/glossary/multispeed_europe.html) or "flexible” integration (Warleigh 2002). 
each time a majority has had to grant sceptical MSs concessions, including many exemptions and opt-outs from common rules in almost each area of EU integration. The EMU and Schengen area, which do not cover all EU members, are the best examples of such opt-outs.

Apart from formal opt-outs, there are two other mechanisms leading to a variable geometry. The first of these was introduced by Article 20 of the Treaty on European Union (TEU) and Articles 326-334 of the Treaty on the Functioning of the European Union (TFEU) under the name of the enhanced co-operation. It concerns areas of non-exclusive EU competences, requires participation of at least nine EU MSs, and shall remain open to others at any time. The Council's decision authorising such co-operation is considered as the last resort measure when "the objectives of such cooperation cannot be attained within a reasonable period by the Union as a whole" (Article 20.2 of TEU). So far, this mechanism has been used only in respect to minor initiatives such as a divorce law.

Another possibility to initiate new areas of integration or co-operation among the interested MSs is to conclude separate inter-governmental treaties, formally outside the system of EU Treaties, but often resulting in setting new mandates and tasks for the EU governing bodies, in particular, for the European Commission. The recent examples of such initiatives include the Treaty on the European Stability Mechanism (ESM, operational since October 2012), and the Treaty on Stability, Coordination and Governance in the EMU (the so-called Fiscal Compact, in force since January 1, 2013).

The variable geometry offers both advantages to the European integration process and negative side effects. On the one hand, it allows moving forward with the integration process despite the objections of some MSs, a very tempting approach in the era of rising Euroscepticism. ${ }^{8}$ If the particular initiative proves successful, it can create a positive example and encourage countries either originally sceptical or just unprepared to accept the new project to join later. This was exactly the history of the Schengen area, which originally (1985) started as the intergovernmental agreement of five MSs to eventually become part of the Amsterdam Treaty in 1997 (see Section 2).

However, the instruments of variable geometry may also create durable divisions within the EU (the multi-speed Europe) with formal or informal opt-outs as in the case of the EMU and Schengen. This can happen if the reservations of individual MSs to deepen integration are driven by long-term strategic preferences

8 Grabbe - Lehne (2016) advocate a variable geometry and flexible membership of different EU projects as the best way to contain centrifugal forces in the post-Brexit environment. In the same vein, Adebahr (2016) suggests "different levels of integration" as the long-term organising principle of the European project. 
to retain maximum national sovereignty (the case of UK) rather than short-term tactical considerations (lobby pressures or the perspective of national elections). Permanent opt-outs do not serve solidarity within the EU (as demonstrated by the EFC and the 2015-2016 refugee crisis) and often lead to the self-isolation and alienation of opt-out holders in respect to common policies (example of the UK).

In an extreme-case scenario, instruments of variable geometry may lead to an "integration à la carte", with strong incentives for individual MSs to focus on short-term political interests rather than long-term integration benefits, and the weakening and even partial institutional disintegration of EU governing bodies, as various narrower integration circles will require their own management and co-ordination mechanisms.

The above-analysed integration asymmetries and loopholes as well as the principle of variable geometry did not create serious challenges in the relatively tranquil pre-crisis times. However, in the period of multiple crises (see Section 1), they confirm the internally incoherent EU institutional architecture and blurred divisions of responsibility between the national and the Union's level. Limited competences and instruments in the hands of EU governing bodies (the case of the refugee crisis of 2015-2016) as well as necessity and tradition to seek the consensus of all MSs make the EU decision-making process complex, lengthy, often inefficient, and non-transparent to the broader public. As a result, they provide Eurosceptics with easy anti-integration arguments such as those about inability of the EU to address various crises and challenges, non-transparent "Brussels bureaucracy", democratic deficit in EU decision-making process, and others.

\section{TOWARDS A FUNCTIONAL AND PRAGMATIC INTEGRATION BLUEPRINT}

The result of the Brexit referendum and the perspective of the UK's departure from the EU have provoked a new round of discussion on the future of the European integration process. While we are not going to enter the purely political dimension of this debate (often guided by the short-term tactical interests of individual national governments or political parties), we believe that a serious reflection on how to improve the existing integration architecture to make it more resilient to new economic and political shocks is urgently needed. A diagnosis of the architecture's major asymmetries and gaps presented in Section 3 will serve as the starting point. In addition, we will discuss in Section 4.1 the theoretical foundations of such an analysis. Based on both, we will try to figure out areas (political and economic) where more integration is needed and those where reducing the competences of the EU governing bodies could provide benefits. 


\subsection{The theory of fiscal federalism and the subsidiarity principle}

When discussing the economic rationale of EU integration, the theory of fiscal federalism should serve as primary guidance. This theory helps us understand "which functions and instruments are best centralized and which are best placed in the sphere of decentralized levels of government" (Oates 1999: 1120).

Thus, discussions about the perspective of EU integration should start from a functional analysis aimed at identifying those policy areas and public goods where the centralisation of competences and resources could either offer increasing returns to scale or help address cross-border externalities. ${ }^{9}$ As a result, any new area of integration (or closer integration in the policy fields already delegated to the EU level) should be justified by the potential benefits of pooling resources to carry out common policies and provide supranational public goods rather than by the very idea of an "ever closer union" itself. ${ }^{10}$

This means that the potential benefits of greater centralisation in any policy areas should outweigh their potential costs in the form of the lower efficiency of centralised decision-making and expenditure (as compared to the decentralised), wrong policy incentives on the national level (risk of moral hazard and free riding), or redistribution conflicts between members states.

In its Preamble and Article 5, the TEU declares the principle of subsidiarity, which must serve as another guideline in the debate on EU integration architecture. According to this principle, the functions of higher levels of government should be as limited as possible and should be subsidiary to those of lower levels (Mortensen 2004). Recommendations based on the subsidiarity principle do not need to be always identical with those justified by the theory of fiscal federalism: the latter may favour more federalist solutions than the former. Nevertheless, in practical terms, we do not see serious potential conflicts between the two.

\subsection{Non-economic agenda}

Unsurprisingly, in the light of the analysis in Sections 2 and 3, the strongest arguments in favour of further transfers of competences and pooling resources on the EU level relate to the non-economic spheres of governance, although many of them have also their economic dimension.

9 The examples of such analyses are provided by Berglof et al. (2003) and Wyplosz (2007, 2015).

10 The Preamble of the TEU refers to continuation of "the process of creating an ever closer union among the peoples of Europe, in which decisions are taken as closely as possible to the citizen in accordance with the principle of subsidiarity". 
For example, the dramatic experience of the recent refugee crisis suggests the urgency of completing the institutional architecture of the Schengen area. This is crucial to avoid the danger of its disintegration, which would create a serious blow to both freedom of travel (one of the most popular elements of European integration) and the SEM (see Gros 2015 and Wolff 2016 on the economic benefits of Schengen).

The strengthening of the Schengen system should include a set of measures aimed at building an effective protection of common external borders, the joint management of both political and economic migrants flows, designing a common policy, co-operation with third countries, and the further harmonisation of JHAand migration-related regulations on national level. More specifically, there is an urgent need to beef up border protection and refugee admission capacities in the frontier countries/regions with the help of the EBCG, to reform the common asylum system with the aim of fair burden sharing between MSs in the accommodation and adaptation of refugees, to further harmonise visa policies, to eliminate free-riding behaviour on a national level (such as encouraging the movement of refugees or illegal immigrants to other MSs or granting resident permits to nonEU nationals in exchange for country-specific investment commitments), to develop common consular services, etc. Some of these steps started to be discussed and even adopted in late 2015 and 2016.

Going beyond the recent refugee crisis and in the context of a shrinking working-age population, the EU must work out a joint and long-term oriented migration policy (Vimont 2016). Such a policy should also involve a strong public education component, explaining the economic rationale of migration and fighting xenophobia.

Next in line is the area of internal security, home, and judicial affairs, especially in the context of the increasing threat of international terrorism. Progress in this sphere is also important for a smooth functioning of the Schengen area and the continuation of the free movement of people.

In the context of increasing external security challenges, especially in the closest EU neighbourhood such as MENA and FSU, the CFSP should also be strengthened, in the first instance, by reducing the veto power of individual MSs. According to Article 25 of TEU, all decisions in this area are taken unanimously, which sometimes makes the CFSP a hostage of short-term narrow lobbyist interests in individual MSs. The process of the semi-annual renewal of EU sanctions against Russia in response to its annexation of Crimea and its intervention in Donbass (since 2014) provides a very good example of EU vulnerability in this regard. 
Building common defence capacities is another area of huge potential returns to scale, mainly by reducing the duplication of defence effort in each member state (Briani 2013). Despite the existing Treaty's provisions (Article 24.1 of TEU), progress to date has been minimal due to the political reservations of the UK and others. In the context of Brexit, the interest in defence integration has increased, as demonstrated by the informal meeting of heads of $27 \mathrm{EU}$ states and governments (without the UK) in Bratislava on September 15, 2016 (Solana 2016).

Other areas of potential returns to scale and cross-border externalities include environmental and climate change policies. The latter, being an example of truly global public good, still remains largely in the hands of national governments, subject to only limited coordination on the EU level.

\subsection{Completing the SEM}

Despite substantial progress in building the SEM, this fundamental component of the entire EU project is far from being completed. There are still important market segments such as financial services, audiovisual services, energy, transportation, telecommunication, and transaction modes, for example e-commerce, where serious barriers to cross-border traffic remain in force. Most have an indirect character, i.e., it originates from the insufficient harmonisation of national legal and regulatory regimes (in the case of the financial sector and the capital market), continuous national licensing (telecommunication and audiovisual services), public ownership of key service providers (energy, transportation, other utilities), lack of the harmonisation of corporate taxation, labour and social legislation, language requirements, etc.

It should in all fairness be noted that the policy agenda of the European Commission of President Juncker includes several projects aimed to address at least part of the existing barriers (European Commission 2015). This includes building the single digital, capital, and energy markets, the elimination of intra-EU roaming fees in telecommunication services, the introduction of the Common Consolidated Corporate Tax Base (CCCTB, which is also important for limiting cross-border tax arbitrage), completing the Banking Union (even if it is de facto limited to EMU members), and others.

The limited membership in the euro zone is another source of cross-border transaction costs within the EU, often more serious than "classical" trade protectionism instruments. From an economic perspective, a common currency is an integral part of the single market architecture, even if for political reasons it 
is considered as another integration project, subject to different membership criteria. Furthermore, from a historical perspective, EMU membership proved the most powerful factor of variable geometry (see Section 3), leading to an increasing degree of internal differentiation between euro "ins" and "outs".

To make SEM complete, but also to reduce the potential sources of macroeconomic turbulence, especially in the less matured economies of Central Europe, those MSs who do not possess an opt-out option (all except the UK and Denmark) should set the realistic and credible scenarios of joining the EMU over the next, let say, 5-10 years. On the other hand, the EMU incumbents should not discourage "outs" from accession as it happened in the past (in the case of Bulgaria).

\subsection{Integration architecture related to the monetary union}

The EFC and a near-Grexit in July 2015 (see, e.g., Darvas - Wolff 2015; Dabrowski 2015a) triggered a debate on the supposedly incomplete architecture of a monetary union (see Dabrowski 2015b for an overview). However, unlike in the case of repairing the Schengen area, the opinions of what should be done to increase the monetary union's resilience to adverse shocks differed substantially.

The dominant view was that a monetary union must be accompanied by a fiscal and political union in order to survive. Surprisingly perhaps, this was the opinion of both the supporters and opponents of the euro project. However, while the former (e.g. De Grauwe 2006; Wolff 2012) believed this was both possible and desirable, the latter (e.g. Feldstein 1997, 2012) doubted it would ever happen due to a long historical tradition of sovereign nation states in Europe.

Empirically, the US served most frequently as the reference for this view (e.g., Bordo et al. 2011; Henning - Kessler 2012; Gros 2013), which might be justified by the similar size of their economies, their global importance, and the role of the US as the EU's major partner and competitor. However, such comparisons overlook the process of the historical evolution of the US federation, which is much more centralised today than it was at the beginning of $20^{\text {th }}$ century, not to speak of the first half of $19^{\text {th }}$ century, including its monetary and fiscal dimensions (Frieden 2016). It also disregards other historical and contemporary experi-

11 To a large degree, this was a side-effect of the UK's reluctance to join new integration initiatives. At the same time, the UK government was ready to accept further economic integration steps within the EMU aimed, at least formally, at increasing single currency resilience to potential adverse shocks. This was the main reason that the Banking Union was initiated within the EMU instead of EU-28, even if it is a de facto measure to integrate a single market of financial services. 
ences of monetary unions (e.g., Cohen 2008; Deo et al. 2011; Dabrowski 2015b), including those formed by sovereign states.

The two largest contemporary monetary unions outside Europe, the West African Economic Monetary Union and the Central African Economic and Monetary Community, have virtually no political and fiscal integration, and their trade and economic integration is still at a rather initial stage, but they have used a common currency (the CFA franc) since 1945, i.e. for over 70 years.

The conclusions that can be drawn from this debate can be summarised as follows: while deeper fiscal and political integration (beyond what has been accomplished so far) is not critical for EMU survival, the theory of optimum currency areas as elaborated by Mundell (1961) and McKinnon (1963) suggests that a greater factor mobility and some fiscal redistribution at a federal level can decrease adjustment costs in case of asymmetric shocks. This underlines, once again, importance of deepening the SEM, completing the Banking Union project, and market liberalisation on a national level (Fuest - Peichl 2012; Issing 2013; Balcerowicz 2014; Draghi 2015). The cushioning and countercyclical role of fiscal policy at the EU level should be built up gradually as a result of the overall progress in the integration process (i.e., delegating new mandates to the EU) and accompanying the increasing size of the EU budget (Section 5) rather than by the creation of any special fund as suggested by De Grauwe (2006); Wolff (2012); Cottarelli (2012b).

On the other hand, EFC experience points to the importance of fiscal discipline in ensuring the stability and sustainability of the monetary union (see Section 6).

\subsection{Deregulation agenda}

Some existing EU mandates do not necessarily meet the test of optimal assignment of functions and resources as suggested by the theory of fiscal federalism and the subsidiarity principle. This relates, in first instance, to the Common Agriculture Policy (CAP), which represents a clear case of overregulation leading to market distortions, resource mismanagement, and external trade protectionism (see Bureau 2012 on CAP evolution and the remaining challenges). The same concerns various detail regulations of markets of goods, services, and labour, some of them captured by various sectoral lobbies. However, in most cases of European overregulation, the recommended solution is deregulation, i.e. allowing market forces to decide, rather than the devolution of EU excessive regulatory power to national governments. The latter will not improve business and investment climate; instead, it will create new barriers to cross-border transactions. 
Again, one should admit that the European Commission of President Juncker declared deregulation to be one of its key policy goals, under the label "Better Regulation Agenda". ${ }^{2}$

\subsection{Better rules enforcement}

Unlike in the case of many other integration projects, the EU governing bodies, the European Commission in the first instance, have been granted several law enforcement instruments aimed at pushing member countries to comply with the Treaties and EU secondary legislation. Nevertheless, these instruments are far from being perfect. While they work relatively well, although often with a considerable time lag in respect to national legislation that contradicts the SEM rules in their broad sense (including environmental and health standards), they remain largely ineffective in enforcing fiscal discipline rules (Section 6). Their effectiveness is also questionable in preventing MSs from breaching fundamental principles of liberal democracy and the rule of law as it has happened in Hungary since 2011 and Poland since 2015.

The solution seems to be granting the European Court of Justice the mandate to invalidate national legislations, which do not comply with the EU Treaties, including the Charter of Fundamental Rights and EU secondary legislation.

\section{REFORMING THE EU BUDGET}

The size of the EU budget has oscillated around 1\% of the EU's Gross National Income (GNI) for a long time and its own revenues are not allowed to exceed $1.23 \%$ of the EU's GNI. ${ }^{13}$ Its expenditures must be closely matched by revenues. The EU is allowed neither to borrow, nor to accumulate budget surpluses (the latter must be returned to MSs).

The EU budget in its current structure is dominated by cross-country transfer programmes such as the CAP, the Cohesion and Structural Funds, foreign aid, plus the costs of functioning EU institutions. Financing European public goods such as research, environmental programmes, JHA, external border protection, assistance to refugees, CFSP, etc., plays a secondary role (see Swidlicki et al. 2012 for a detailed analysis). Many of them remain, in fact, unfunded or underfunded at the EU level and must rely on national funding. 
This is another source of the EU's institutional weakness. The implementation of common rules and policies relies, to a large extent, on the administrative and financial resources of individual MSs and their political will. For example, a national border police/guard is in charge of protecting the EU external borders, a national customs service in charge of the collection of customs duties and the enforcement of the common external trade policy, and public administration on the national or subnational level in charge of the implementation of joint regulatory standards. They are all paid from national budgets. The level of their remuneration, skills, quality, and integrity vary between individual MSs.

One could imagine different political incentives at national and subnational levels in respect to refugee accommodation, if the EU budget was able to offer full funding of this operation. The same applies to other common policies.

The current expenditure structure of the budget results from past compromises on key integration steps. For example, the Cohesion Fund was a by-product of negotiations on the Maastricht Treaty in early 1990s, the price of convincing economically less advanced MSs to back the idea of the EMU and to address their concerns that the fiscal discipline required by the Treaty changes could result in insufficient investment in public capital (Mortensen 2004; OECD 2007). The adoption of the Multiannual Financial Framework (MFF) requires a unanimous decision by all MSs, ${ }^{14}$ which additionally narrows the room for any radical changes in the budget size and its expenditure structure.

The dominance of cross-country transfers makes net donor countries reluctant to increase the EU's budget size, which was clearly demonstrated during the political negotiations on the MFF for 2014-2020. On the other hand, the net recipient countries, especially those from Central, Eastern and Southern Europe, are interested in continuing transfers on the previous or even increased levels. In some cases, net transfer inflows have approached 5\% of their GDP (Heinen 2011).

The above picture changed with the creation of the European Financial Stability Facility in 2010, which was replaced by the European Stability Mechanism (ESM) in 2012, as a result of the sovereign debt crisis in several euro zone countries. The ESM's lending capacity is EUR 500 billion, i.e. $c a .5 \%$ of the euro zone's annual GDP. However, the maximum ESM lending capacity cannot be mechanically compared with the size of the EU regular budget because the former represents a one-off stock granted by the member countries and the latter

14 Formally, the MFF is subject to the co-decision procedure of the Council and the European Parliament. Usually, the European Parliament is in favour of a larger EU budget, but the effective veto power of each individual member state in the Council makes its bargaining position weaker. The adoption of an annual EU budget is also subject to co-decision, but requires only a QMV in the Council (instead of unanimity as in the case of MFF), which gives the European Parliament more room to influence the eventual decision. 
is a regular annual flow. The EFSF and ESM also raise controversies on grounds that they undermine market-based fiscal discipline on the national level and contradict Article 125 of the TFEU, i.e. the no bail-out clause (see Section 6).

To make the analysis complete, one should also mention EU-funded investment institutions, which perform some quasi-fiscal tasks such as the European Investment Bank (EIB) and the European Investment Fund (EIF). Since 2014, both have become involved in the implementation of the European Commission's flagship Investment Plan for Europe, the so-called Juncker Plan.

On the revenue side, only the so-called "traditional own resources" 15 can be considered a sort of "federal" taxation. The two other "own resources", i.e. from value added tax (VAT) and the one based on GNI are calculated according to complicated country-specific formulas. "Other revenue" includes taxes on the salaries of EU staff, contributions from non-EU countries to certain programmes, and fines, for example, on companies for breaching the EU competition law. In addition, some net donor MSs (the UK, Sweden, the Netherlands, Germany, and Austria) enjoy various kinds of rebates. Summing up, most of the EU budget revenue comes from the financial contribution of MSs, an amount that is individually negotiated in the process of adopting a MFF (which requires the unanimity of all MSs).

As discussed above, the efficient implementation of the already-existing EU mandates and policies (aimed at delivering pan-European public goods), not to speak about potential new ones, will be difficult without an increase in the respective expenditure items of the EU budget. This, in turn, requires either increasing the size of the EU budget, or changes in its expenditure structure (downsizing allocations for CAP and cohesion and structural funds). To achieve this goal, replacing the unanimity principle with QMV mechanism in the Council's decisions on the MFF seems to be crucial. Perhaps Brexit can make such a change easier, given the UK's continuous push to minimise the role and size of the EU budget.

On the revenue side, any substantial increase in the size of the EU budget beyond the current range of $1 \%$ of GNI will probably require the development of direct revenue sources such as pan-European taxes. At this stage of the debate on the future of the EU, it is difficult to predict which kind of "federal" taxes may emerge in the future. Most likely, it may be new forms of indirect taxation on activities having a strong cross-border spillover.

Abandoning the unanimity rule in adopting the MFF, increasing the size of the EU budget, and developing "federal" taxation would have to increase the role and political importance of the European Parliament (see Section 7).

$1575 \%$ of customs duties on imports from outside the EU and sugar levies; the remaining $25 \%$ goes to national budgets to compensate for the cost of collection. 


\section{REBUILDING FISCAL DISCIPLINE WITHIN THE EU AND EMU}

\subsection{The importance of fiscal discipline}

Fiscal discipline is very important for currency stability (Wyplosz 2013) and, more broadly, financial and macroeconomic stability in any country/territorial entity. However, it becomes even more important within federations, confederations, and closely integrated economic blocks, due to cross-border spillovers and contagion, and because of more opportunities to free ride at the cost of neighbours and the moral hazard problem (expectation of a bail-out). This was confirmed by the EFC (especially in the case of Greece), and the experience of those federal states that failed to ensure the fiscal discipline of their subnational governments. Countries such as Argentina, Brazil (see Bordo et al. 2011; Cottarelli 2012b), Mexico, Russia, and Spain, which provided their sub-national governments with bail-outs have suffered serious fiscal and monetary stability problems at the federal level.

Thus, fiscal discipline should be considered an important common public good for the entire EU, not only for the euro zone.

\subsection{Market discipline vs. fiscal rules}

Fiscal discipline may be ensured by market mechanisms (danger of sovereign default) and formal fiscal rules (formal constraints), or a combination of both. In turn, fiscal rules can be divided into fiscal targets and fiscal procedures, which are either imposed by a federal centre, self-imposed by a sub-federal entity, or negotiated by both (Eyraud - Gomez Sirera 2013).

Historical experience demonstrates the superiority of market discipline: the credible danger of default serves as the strongest incentive to put sub-federal finances in order (Bordo et al. 2011; Henning - Kessler 2012). For example, the US federal authorities have not bailed out any state since the 1840s and this has created a strong incentive for states to adopt fiscal discipline rules in their constitutions and secondary legislations (the federal government has imposed none of them). Similarly, counties and municipalities cannot expect a bail-out from either the state or the federal government. The similar "no bail-out" practice governs the Canadian and Swiss federations (Bordo et al. 2011; Cottarelli 2012b). 


\subsection{The EU fiscal discipline mechanism and its failure}

The original EU/EMU mechanism of fiscal stability as determined by the Maastricht Treaty was based on both market discipline and fiscal rules. The former was built around the "no bail-out" clause and the ban on debt monetisation by the ECB or the national central banks in MSs that have not yet introduced the euro. ${ }^{16}$ On other hand, Article 126 of the TFEU, the accompanying Protocol No. 12 and the EU's secondary legislation, i.e. the Stability and Growth Pact (SGP), determined fiscal rules. They include numeric criteria on the maximum annual fiscal deficit (3\% of GDP) and gross public debt level (60\% of GDP), the socalled Maastricht criteria, backed by administrative and financial sanctions for breaching them within the Excessive Deficit Procedure (EDP). As a result of GFC and EFC, those initial fiscal rules were further amended by the so-called Six-Pack (December 2011) and Two-Pack (May 2013) legislations, the European Semester procedure (since November 2010), and the Fiscal Compact (since January 2013).

However, as shown in Tables 1 and 2, the EU fiscal discipline mechanism does not work in practice. Financial markets have never taken the "no bail-out" clause very seriously, as demonstrated by very low yield spreads prior to the GFC and since 2013, in spite of big differences in the fiscal positions of individual countries. It was finally compromised with the adoption of the first financial assistance package to Greece in May 2010 and creating the EFSF and ESM bailout facilities. Before the first rescue programme for Greece, in 2008-2009, the EU also provided balance-of-payment support to three non-EMU MSs, Hungary, Latvia, and Romania, part of which could be used for budget needs. Thus, the "no bail-out" principle was replaced by a policy of conditional bail-out (financial assistance in exchange for a country's commitment to fiscal adjustments and necessary reforms).

De facto suspending the market discipline mechanism in 2010 was to be compensated by the stronger fiscal rules on both the EU and national level backed by stronger sanctions, including financial ones. However, their enforcement, especially on the EU level, has not improved. The large number of various exceptions written into the EDP is one reason of this failure.

Another, and perhaps more important, cause relates to the collective action problem when there is no sufficient majority among MSs in favour of fiscal rules enforcement. As illustrated by Tables 1 and 2, most of EU MSs do not comply with the Maastricht criteria and are frequently subject of EDP. The same reason can explain the repeated circumvention of the "no bail-out" clause since 2010.

16 Articles 123 and 125 of TFEU. 
Having high public indebtedness, high debt exposures to sovereign debt of countries in trouble, and fragile banking systems impaired by the GFC, most of EU MSs have been afraid of cross-country crisis contagion. This has decreased the political appetite of MSs to enforce the "no bail-out" principle.

Finally, the economic and political debate during the GFC and EFC was influenced by advocates of continuous fiscal stimulus, or at least by those who

Table 1. General government gross public debt, in \% of GDP, 1999-2015

\begin{tabular}{l|r|r|r|r|r|r|c}
\hline Country & 1999 & 2003 & 2007 & 2010 & 2013 & 2015 & $\begin{array}{c}\text { Change } \\
1999-2015\end{array}$ \\
\hline Austria & 66.4 & 65.5 & 64.8 & 82.4 & 80.8 & 86.2 & + \\
\hline Belgium & 114.4 & 101.1 & 87.0 & 99.7 & 105.2 & 106.1 & - \\
\hline Bulgaria & 79.4 & 45.6 & 17.5 & 14.3 & 17.2 & 26.3 & - \\
\hline Croatia & 28.1 & 37.5 & 37.1 & 57.0 & 82.2 & 86.7 & + \\
\hline Cyprus & 55.9 & 63.4 & 53.6 & 56.3 & 102.5 & 108.9 & + \\
\hline Czech Rep. & 15.2 & 28.1 & 27.8 & 38.2 & 44.9 & 40.3 & + \\
\hline Denmark & 56.8 & 46.2 & 27.3 & 42.9 & 44.7 & 45.5 & - \\
\hline Estonia & 6.0 & 5.6 & 3.7 & 6.6 & 9.9 & 9.7 & + \\
\hline Finland & 44.0 & 42.7 & 34.0 & 47.1 & 55.4 & 62.5 & + \\
\hline France & 60.2 & 64.2 & 64.4 & 81.7 & 92.4 & 96.1 & + \\
\hline Germany & 60.0 & 62.9 & 63.5 & 81.0 & 77.1 & 71.0 & + \\
\hline Greece & 98.9 & 101.5 & 103.1 & 146.3 & 177.7 & 176.9 & + \\
\hline Hungary & 59.9 & 57.6 & 65.6 & 80.6 & 76.8 & 75.3 & + \\
\hline Ireland & 46.6 & 29.9 & 23.9 & 86.3 & 119.5 & 78.7 & + \\
\hline Italy & 109.7 & 100.5 & 99.8 & 115.4 & 129.0 & 132.7 & + \\
\hline Latvia & 11.8 & 13.9 & 7.2 & 40.3 & 35.9 & 34.9 & + \\
\hline Lithuania & 28.1 & 20.9 & 16.7 & 36.3 & 38.8 & 42.8 & + \\
\hline Luxembourg & 7.1 & 6.9 & 7.8 & 20.1 & 23.3 & 21.5 & + \\
\hline Malta & 69.5 & 68.7 & 62.4 & 67.6 & 68.4 & 64.0 & - \\
\hline Netherlands & 58.2 & 49.3 & 42.4 & 59.3 & 67.7 & 65.1 & + \\
\hline Poland & 39.6 & 46.6 & 44.2 & 53.3 & 56.0 & 51.3 & + \\
\hline Portugal & 49.0 & 54.7 & 68.4 & 96.2 & 129.0 & $\mathbf{1 2 9 . 0}$ & + \\
\hline Romania & $\mathrm{n} / \mathrm{a}$ & 24.0 & 12.7 & 30.5 & 38.8 & 39.3 & + \\
\hline Slovakia & 47.1 & 41.6 & 29.9 & 40.8 & 55.0 & 52.9 & + \\
\hline Slovenia & 22.0 & 27.0 & 22.7 & 38.2 & 71.0 & 83.1 & + \\
\hline Spain & 62.5 & 47.6 & 35.5 & 60.1 & 93.7 & 99.3 & + \\
\hline Sweden & 61.4 & 49.1 & 38.1 & 37.6 & 39.8 & 43.4 & - \\
\hline UK & 39.6 & 35.8 & 42.2 & 75.7 & 86.0 & 89.0 & + \\
\hline Note: & & & & & & + \\
\hline
\end{tabular}

Note: The bold font indicates estimates of the IMF staff.

Source: IMF World Economic Outlook database, October 2016. 
opposed fiscal tightening. Opponents of "austerity" frequently questioned the rationale of the existing EU fiscal rules and their enforcement (Krugman 2012a, 2012b, 2013; Layard 2012; Soros 2012). In such an intellectual atmosphere, it is not easy to build a political consensus in favour of the strict enforcement of the EU/EMU fiscal rules.

\subsection{Debt mutualisation and monetisation: the wrong sort of federalism}

Some of the proposals considered by their authors as helpful in building genuine fiscal and political union are, in fact, dysfunctional from both an economic and political point of view. They can produce wrong fiscal incentives at a national level, distributional conflict between MSs (as observed during the Greek crisis), and provoke political backlash against deeper integration.

The "Deep and Genuine EMU" proposal of the European Commission (2012) is one of such examples. It suggested the creation of a European Redemption Fund, an idea originally developed by the German Council of Economic Advisors, which meant a step further towards a conditional bail-out policy as compared to the current solutions. On the other hand, it wanted to further increase its prerogatives to monitor national budgets (currently under the European Semester procedure), including some kind of veto power in respect to national budget decisions. ${ }^{17}$ This would make EU fiscal rules increasingly intrusive and incompatible with the dominant political and legal architecture of the EU, i.e. a sort of limited federation or confederation. Furthermore, in the context of rising Euroscepticism, such an intrusiveness could serve only as convenient argument against the "Brussels bureaucracy" in the hands of populists of various political colours.

Referring to Eyraud - Gomez Sirera's (2013) classification of arrangements aimed at constraining the fiscal policy's room for manoeuvre of sub-federal entities, this would mean moving from the fiscal rules imposed by the centre (the current regime) to direct controls by the centre. Fortunately, the "Five-Presidents Report" (Juncker et al. 2015) does not follow the European Commission (2012) proposals of the European Redemption Fund and direct controls of national budget policies. Nor does it mention any other form of debt mutualisation mechanism.

Debt mutualisation proposals via issuing Eurobonds and the creation of a lender of last resort (LOLR) facility for governments were frequently articulated during the EFC. If implemented, they would mean moving from conditional to unconditional fiscal and monetary bail-outs. Some of the Eurobonds proposals

17 Such an instrument is rarely used in federal states: see Cottarelli (2012a). 


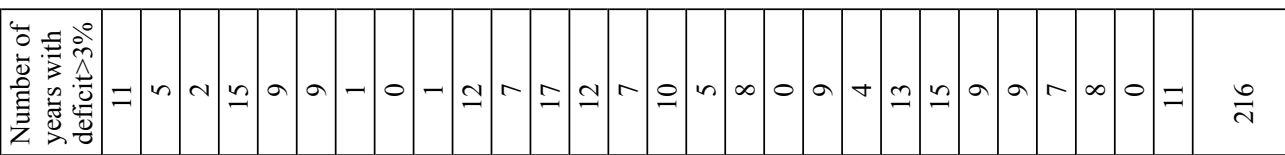

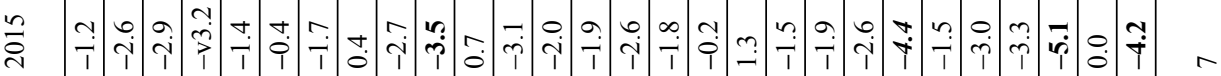

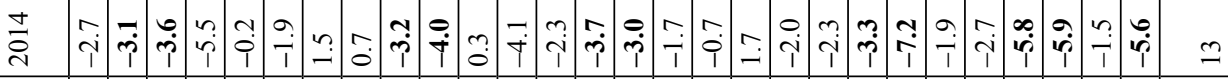

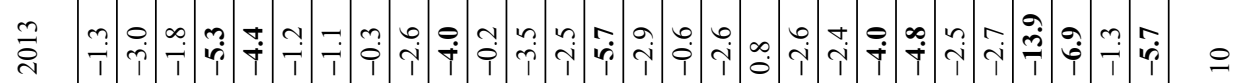

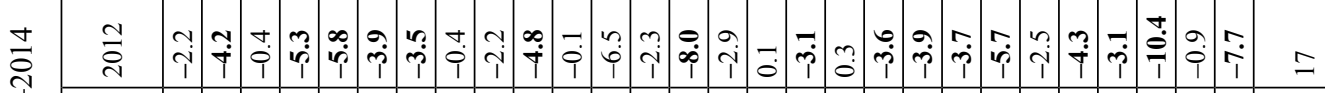

รั

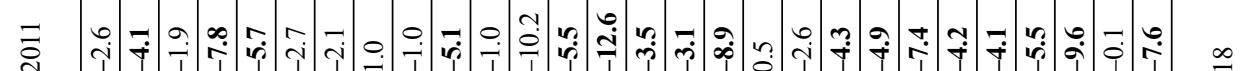

仓ิ

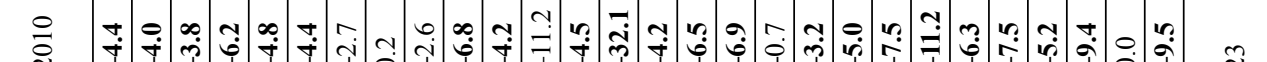

ำ

.

m m +0 m

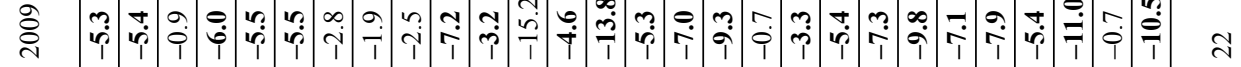

ộ

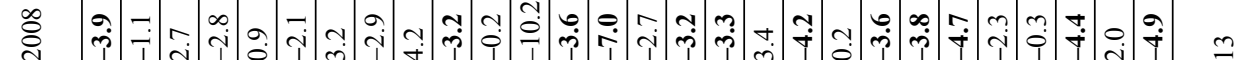

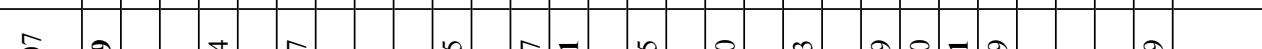

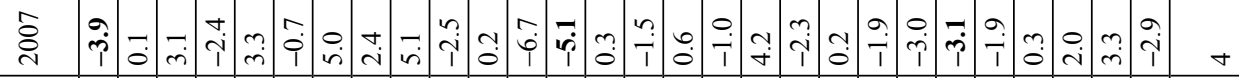

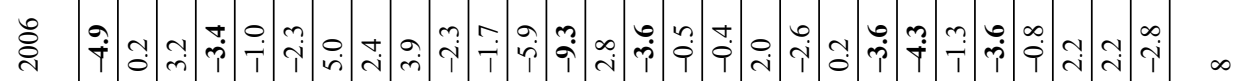

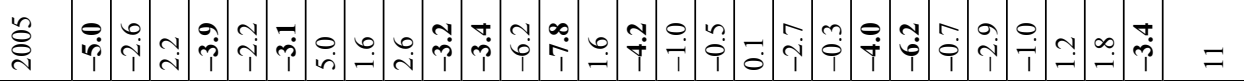

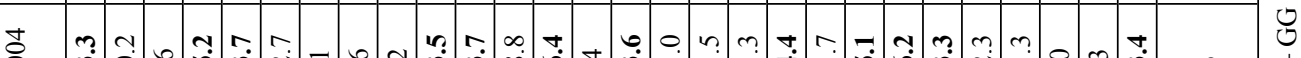

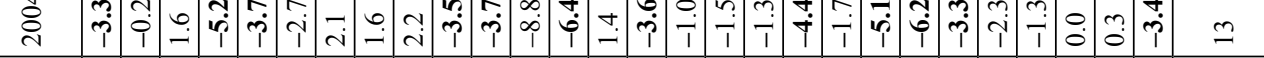

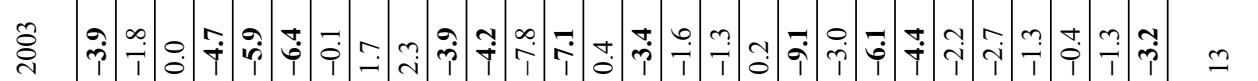

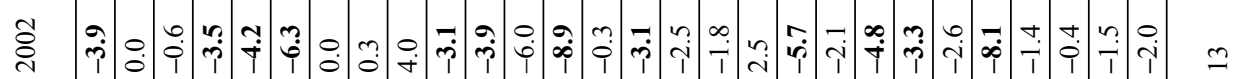

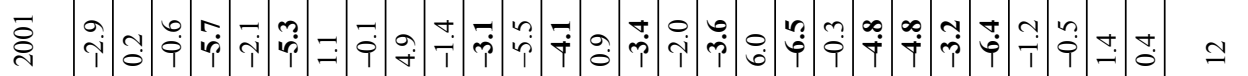

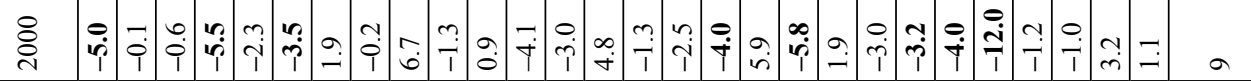

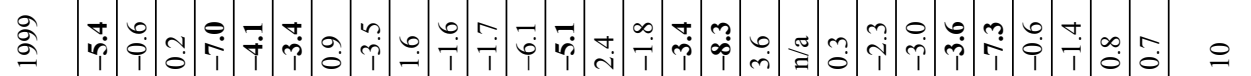

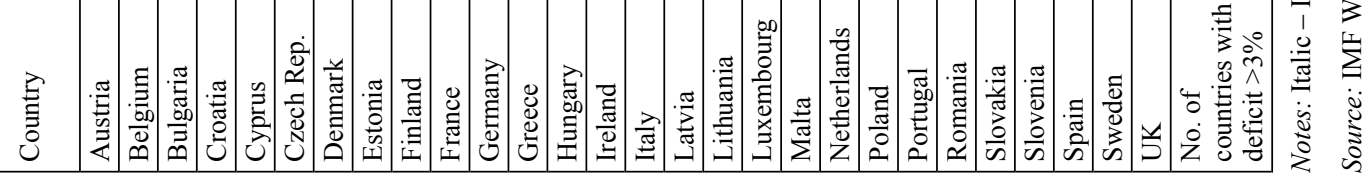


can still be considered as a form of conditional bail-out, e.g. the Blue Bond proposal of Delpla - von Weizsaecker (2010). Others represent either an unconditional bail-out or a bail-out with very weak conditionality (see e.g., Soros 2012; De Grauwe 2013). The idea of Eurobonds might make sense if it served financing EU budget needs, under the condition that the EU would have sufficient own revenue sources in future to pay back this debt. Currently, the gap between EU spending commitments and available budget resources is financed in the form of payment arrears, i.e. by the suppliers and beneficiaries of EU programmes and transfers.

The LOLR proposals call for the unlimited and unconditional commitment of the ECB to purchase debt instruments issued by euro zone governments in the case of market distress (see, e.g., Bofinger - Soros 2011; Layard 2012).

Both proposals have been justified on the grounds of arresting the irrational behaviour of financial markets, avoiding cross-country contagion, and helping governments that are temporarily illiquid, but fundamentally solvent to survive. Again, the fear of potential contagion of over-indebted sovereigns plays a powerful role in this debate.

Unfortunately, both proposals overestimate the fiscal sustainability of leading euro zone countries such as Germany, blur borderlines between illiquidity and insolvency, and ignore the moral hazard problem. In addition, the idea of the LOLR to governments confuses, intentionally or unintentionally, the governments with commercial banks. If taken seriously, it means abandoning the ECB independence, which may have far-reaching negative consequences for euro stability and the political sustainability of the common currency project (based on the principle of price stability and fiscal neutrality of the ECB).

\subsection{Cleaning up Augeas' stables: overhauling the EU fiscal discipline mechanism}

As discussed above, fiscal discipline at the national level should be based, in the first instance, on a credible default threat and national fiscal rules. The EU fiscal rules can play only a supplementary role. If they go too far and become too intrusive, the chances of their effective enforcement will only diminish due to the collective action problem and technical difficulties with the implementability of too complex, arbitrary, and, sometimes, internally incoherent rules.

However, rebuilding market discipline will not be an easy task in the context of the fresh memory of a series of sovereign bail-outs carried out during the GFC and EFC, some of them (such as Greece) remaining unfinished. It will also require rebuilding intellectual and political consensus on the importance of medium- and long-term fiscal sustainability constraints, the economic benefits of a 
low public debt level, and the importance of supply-side reforms in increasing individual countries' growth potential.

In practical terms, the first step to rebuild the credibility of Article 125 of TFEU should be the transformation of the ESM into a fiscal backstop of the Single Resolution Mechanism and future European Deposit Insurance Scheme, and terminating its sovereign bail-out mandate, at least financing new rescue programmes for governments in distress.

The EDP should be maximally simplified by eliminating various exceptions and loopholes as well as stopping using variables such as the potential output, which are the subject of ex-ante forecasts and crudely varying expert judgment errors and, therefore, the subject of political bargaining between a MS and the EC. On the other hand, financial sanctions, which proved unimplementable, should be replaced with automatic political sanctions, for example, suspending voting rights in the Economic and Financial Affairs Council (ECOFIN) once the budget deficit or public debt of a MS breaches Treaty criteria in a systematic way.

Fortunately, as a result of the Six-Pack legislation and the Fiscal Compact, the MSs adopted or strengthened already existing national fiscal rules such as upper deficit and debt limits written into countries' constitutions and secondary legislation. This can help in strengthening fiscal discipline at a national level without the need of further developing bureaucratic and intrusive surveillance procedures at the EU level.

\section{THE INSTITUTIONAL SETUP OF THE FUTURE EU}

In the current institutional setup, the EU "federal" prerogatives are shared, in various proportions, among the European Parliament, the Council, and the European Commission. The delegation of additional competences and policies to the EU level as suggested in this paper, resulting in a larger EU budget, more EU taxation, and reducing the veto power of individual MSs would have to lead to the modification of the current power balance. The role of the European Parliament would increase, at the cost of national legislatures and executives, and the Council, which represents national governments. The role of the European Commission as the executive would also increase accordingly, although under the democratic control of the European Parliament. Some current tasks of the Commission related, for example, to the detailed surveillance of national budgets and macroeconomic policies should be reduced in favour of reinstating market discipline mechanisms.

The increased legislative and control prerogatives of the European Parliament could help in strengthening democratic legitimacy of the EU governing bodies 
and the entire EU project, on the one hand, and in building pan-European political space, on the other. The latter might be further facilitated by institutional measures aimed at forming truly pan-European political parties (rather than the current loose federations of national parties) and changes in election rules to the European Parliament. We mean allocation of a portion of the seats according to centralised pan-European lists of candidates presented by individual pan-European political groups/parties and backed by the presentation of pan-European election programmes. Supporting pan-European media information and political debate space is another step in this direction. All these measures could help in overcoming the current political fragmentation along national lines, which often leads to questioning the sense and possibility of democratic legitimacy on the EU level.

The suggested directions of institutional changes corresponding to the functional division of responsibilities between the EU and national levels (justified by the theory of fiscal federalism and the subsidiarity principle) are much more important for the political sustainability of the European integration project than some purely symbolic gestures. The examples of the latter included the proposal of the Union Minister for Foreign Affairs in the Treaty Establishing a Constitution for Europe (signed in 2004, but not ratified), or the creation of the euro zone's Finance Ministry (Marzinotto et al. 2011). In fact, such institutions exist in the EU, although under different names: the High Representative of the Union for Foreign Affairs and Security Policy and the European External Action Service in case of the CFSP, and the Directorate-General for Economic and Financial Affairs as the EU and EMU "ministry of finance".

\section{SUMMARY AND CONCLUSIONS}

The series of adverse shocks of both economic and political character suffered by Europe since 2008 revealed numerous institutional gaps and asymmetries in the EU integration architecture. Part of them was addressed in the meantime, although not always in the best possible way. We mean, for example, changes in macroeconomic governance and in fiscal discipline mechanism, which led to suspending the "no bail-out" clause and increased the complexity and intrusiveness of EU fiscal rules, and fiscal and macroeconomic surveillance. Nevertheless, there have also been reforms going in the right direction, i.e. increasing the completeness and sustainability of the EU architecture such as strengthening national fiscal rules, the formation of the Banking Union, and the EBCG.

The Brexit referendum of June 23, 2016, delivered probably the most powerful political and economic shock since the very beginning of the EEC/EU project. This is the first historical case of a member state's exit from the EU. Worse, 
it concerns the second biggest EU national economy and an important global player, a country that is a source of high-quality human resources for the entire EU and can serve as a benchmark of good governance and responsible economic policies to others. The Brexit process itself may be lengthy and painful, in both economic and political terms, for both the UK and EU-27 and absorb a large part of political energy and administrative resources, which could otherwise be used for reforming the EU integration architecture and policies.

We are not going to speculate on how the EU-27 will eventually react to Brexit. This may be determined, at least in the short term, by politics at the national level, for example, election timetables in the largest MSs. We also do not enter general debates like "more Europe vs. more national sovereignty", which usually contain a strong ideological and emotional component and are not always concrete enough in terms of detail solutions.

Instead, in this paper, we offer an institutional diagnosis of current integration asymmetries, their historical roots, and a normative analysis of how to remodel the current architecture of European integration to make it more functional, complete, transparent, and capable of providing more global and European public goods. Our analysis employs the theory of fiscal federalism and the subsidiarity principle as the best conceptual framework to achieve the above-stated goals in our opinion.

The results of our analysis provide a strong argument in favour of completing the key integration components of the current architecture, which have been subjects of adverse shocks in recent years: the SEM, the Schengen area, and EMU. This is a matter of their future shock-resilience or even institutional survival. In addition, we point out potential benefits, in terms of both returns to scale and addressing important externalities, of stronger CFSP and common EU defence policy. On the other hand, we make clear that some existing proposals presented in the name of strengthening EU integration architecture are clearly dysfunctional. For example, it concerns all measures, which may undermine market-based fiscal discipline and the "no bail-out" rule.

If the future integration process follows our proposals, it will lead to a larger EU budget and necessity to finance its expenditure out of EU taxes rather than individually negotiated national contributions. Both will strengthen the role of the European Parliament and, hopefully, its democratic legitimacy. Accompanying measures in the area of election law, forming a system of European political parties, and building a media platform of pan-European debate can further strengthen this legitimacy and counteract political fragmentation along national borders.

We are aware that the proposed agenda is not easy to implement, at least in a short-term perspective, which is dominated by the Eurosceptical contagion gen- 
erated by the series of crises and the success of the Brexit referendum. Nevertheless, we hope the EU construction is resilient enough to survive this difficult turning point and move forward. The potential benefits of a continuous integration process should return interest in long-term functional analyses of the sort presented in this paper.

\section{REFERENCES}

Adebahr, C. (2016): A Flexible Europe after the Brexit Vote. Carnegie Europe, Carnegie Europe, Brussels, September 1, http://carnegieeurope.eu/strategiceurope/?fa=64447

Balcerowicz, L. (2014): Euro Imbalances and Adjustment: A Comparative Analysis. Cato Journal, 34(3) (Fall), http://object.cato.org/sites/cato.org/files/serials/files/cato-journal/2014/9/ cj34n3-1.pdf

Berglof, E. - Eichengreen, B. - Roland, G. - Tabellini, G. - Wyplosz, C. (2003): Built to Last: A Political Architecture for Europe. Monitoring European Integration, vol. 12, London, Center for Economic Policy Research.

Bofinger, P. - Soros, G. (2011): Only Way to Stop the Run on Eurozone Debt. Financial Times, November 21, http://www.ft.com/intl/cms/s/0/4f29ab54-1431-11e1-85c7-00144feabdc0.html\# axzz1gRCoxjhP

Bordo, M. D. - Markiewicz, A. - Jonung L. (2011): A Fiscal Union for the Euro: Some Lessons from History. NBER Working Paper, No. 17380, September, http://www.nber.org/papers/ w17380.pdf

Briani, V. (2013): Armaments Duplication in Europe: A Quantitative Assessment. CEPS Policy Brief, No. 297, July 16, https://www.ceps.eu/system/files/PB\%20297\%20Briani\%20Duplication\%20in\%20EU\%20armed\%20forces\%20-.pdf

Bureau, J. C. (2012): Where Is the Common Agricultural Policy Heading? Intereconomics, 47(6): 316-321, November/December, http://archive.intereconomics.eu/year/2012/6/the-commonagricultural-policy-after-2013/

Cohen, B. (2008): Monetary Unions. In: Whaples, R. (ed.): EH.Net Encyclopedia, February 10, http://eh.net/encyclopedia/monetary-unions/

Cottarelli, C. (2012a): European Fiscal Union: A Vision for the Long Run. Presentation at the Gerzensee Conference, November 1-2, IMF Fiscal Affairs Department, https://www.imf.org/ external/np/speeches/2012/110112.htm

Cottarelli, C. (2012b): Fiscal Federations: Lessons for the Design of a European Fiscal Union. Presentation for the ECB-IMF Conference in Frankfurt, December 13, IMF Fiscal Affairs Department, https://www.imf.org/external/np/speeches/2012/121312.htm

Dabrowski, M. (2015a): Greece: from Default to Grexit? Bruegel blog, June 28, http://bruegel. org/2015/06/greece-from-default-to-grexit/

Dabrowski, M. (2015b): Monetary Union and Fiscal and Macroeconomic Governance. European Economy Discussion Paper, No. 013, September, http://ec.europa.eu/economy_finance/publications/eedp/pdf/dp013_en.pdf

Darvas, Zs. - Wolff, G. (2015): Choices after the Greferendum. Bruegel blog, July 6, http://bruegel. org/2015/07/choices-after-the-greferendum/

De Grauwe, P. (2006): On Monetary and Political Union. CESifo Forum, No. 4/2006, http://www. cesifo-group.de/DocDL/forum4-06-focus1.pdf

De Grauwe, P. (2013): Pool Debt, or Face Dangerous Upheavals across Europe. Europe's World, Spring, http://www.europesworld.org/NewEnglish/Home_old/Article/tabid/191/ArticleType/ articleview/ArticleID/22076/language/en-US/Default.aspx 
De Grauwe, P. (2016): Why the European Union will Benefit from Brexit. Ivory Tower, February 22, http://escoriallaan.blogspot.be/2016/02/why-european-union-will-benefit-from.html

Delpla, J. - Von Weizsaecker, J. (2010): The Blue Bond Proposal. Bruegel Policy Brief, 2010/3, May.

Deo, S. - Donovan, P. - Hatheway, L. (2011): A Brief History of Break-ups. UBS Research: Global Economic Perspectives, October 11, www.ubs.com/economics

Draghi, M. (2015): Stability and Prosperity in Monetary Union. Project Syndicate, January 2, http:// www.project-syndicate.org/print/ecb-eurozone-economic-union-by-mario-draghi-2015-1\#

European Commission (2012): A Blueprint for a Deep and Genuine EMU. Launching a European Debate. Communication from the European Commission, COM (2012) 777, November 28, http://ec.europa.eu/archives/commission_2010-2014/president/news/archives/2012/11/pdf/ blueprint_en.pdf

European Commission (2015): Commission Work Programme 2016: No Time for Business as Usual. Communication from the Commission to the European Parliament, the Council, the European Economic and Social Committee and the Committee of the Regions, COM(2015) 610 final, Strasbourg, October 27, http://ec.europa.eu/atwork/pdf/cwp_2016_en.pdf

European Commission (2016): EU-Turkey Agreement: Questions and Answers. European Commission, Press Release Database, March 19, http://europa.eu/rapid/press-release_MEMO-16963 en.htm

Eyraud, L. - Gomez Sirera, R. (2014): Constraints on Sub National Fiscal Policy. In: Cottarelli, C. - Guerguil, M. (eds): Designing a European Fiscal Union: Lessons from the Experience of Thirteen Federations. London: Routledge.

Feldstein, M. (1997): EMU and International Conflict. Foreign Affairs, 76(6): 60-76, https://www. foreignaffairs.com/articles/europe/1997-11-01/emu-and-international-conflict

Feldstein, M. (2012): The Failure of the Euro. Foreign Affairs, January/February, https://www. foreignaffairs.com/articles/europe/2011-12-13/failure-euro

Frieden, J. (2016): Lessons for the Euro from Early US Monetary and Financial History. Bruegel Essay and Lecture Series, May 25, http://bruegel.org/wp-content/uploads/2016/05/essay_ frieden_may16.pdf

Fuest, C. - Peichl, A. (2012): European Fiscal Union: What Is It? Does It Work? And Are There Really 'No Alternatives'? IZA Policy Paper, No. 39, March, http://ftp.iza.org/pp39.pdf

Grabbe, H. - Lehne, S. (2016): How to Build a More Flexible EU After Brexit? Carnegie Europe, Brussels, September 8, http://carnegieeurope.eu/2016/09/08/how-to-build-more-flexible-euafter-brexit/j531

Gros, D. (2013): Banking Union instead of Fiscal Union? In: Allen, F. - Carletti, E. - Gray, J. (eds): Political, Fiscal and Banking Union. European University Institute, Florence - Wharton Financial Institutions Center University of Pennsylvania, Philadelphia, US.

Gros, D. (2015): Schengen and European Security. Project Syndicate, December 10, https://www. project-syndicate.org/commentary/schengen-open-borders-help-security-by-daniel-gros-2015-12

Heinen, N. (2011): EU Net Contributor or Net Recipient. Just a Matter of Your Standpoint? Deutsche Bank Research, http://www.dbresearch.com/PROD/DBR_INTERNET_EN-PROD/ PROD0000000000273546.pdf

Henning, C. R. - Kessler, M. (2012): Fiscal Federalism: US History for Architects of Europe's Fiscal Union. Bruegel Essay and Lecture Series, January 10, http://bruegel.org/wp-content/uploads/imported/publications/essay_fiscfed_web_01.pdf

Issing, O. (2013): The Case for Political Union Isn't Convincing. Europe's World, Summer, http:// www.europesworld.org/NewEnglish/Home_old/Article/tabid/191/ArticleType/ArticleView/ ArticleID/22139/language/en-US/Default.aspx

Juncker, J-C. et al. (2015): Completing Europe's Economic and Monetary Union. European Commission, June 22, http://ec.europa.eu/priorities/economic-monetary-union/docs/5-presidentsreport_en.pdf 
Kartnitschnig, M. - Hirst, N. (2016): A Long, Costly and Messy Divorce. Politico, March 2, http:// www.politico.eu/article/brexit-eu-divorce-uk-cameron/

Krugman, P. (2012a): European Crisis Realities. The New York Times, February 25, http://krugman. blogs.nytimes.com/2012/02/25/european-crisis-realities/

Krugman, P. (2012b): Europe's Austerity Madness. The New York Times, September 27, http:// www.nytimes.com/2012/09/28/opinion/krugman-europes-austerity-madness.html?_r=0

Krugman, P. (2013): Austerity Europe. The New York Times, February 23, http://krugman.blogs. nytimes.com/2013/02/23/austerity-europe-2/

Layard, R. (2012): The Tragic Error of Excessive Austerity. VoxEU.org, July 6, http://voxeu.org/ vox-talks/tragic-error-excessive-austerity

Marzinotto, B. - Sapir, A. - Wolff, G. (2011): What Kind of Fiscal Union? Bruegel Policy Brief, No. 2011/6, November, http://bruegel.org/wp-content/uploads/imported/publications/111124 pb_2011-06_.pdf

McKinnon, R. (1963): Optimum Currency Areas. American Economic Review, 53(4): 717- 725.

Mortensen, J. (2004): Economic Policy Coordination in EMU: What Role for the SGP? CEPS Working Document, No. 202, June, https://www.ceps.eu/system/files/book/1127.pdf

Mota, P. R. - Costa Fernandes, A. L. - Nicolescu, A. G. (2015): The Recent Sovereign Debt Crisis in the Eurozone: A Matter of Fundamentals? Acta Oeconomica, 65(1): 1-25.

Mundell, R. (1961): A Theory of Optimum Currency Areas. American Economic Review, 51(4): $657-665$.

Oates, W. E. (1999): An Essay on Fiscal Federalism. Journal of Economic Literature, 37(3): 11201149.

OECD (2007): OECD Economic Surveys: European Union. 2007/11, September.

Solana, J. (2016): European Defense Integration Now. Project Syndicate, September 20, https:// www.project-syndicate.org/print/european-defense-integration-now-by-javier-solana-2016-09

Soros, G. (2012): Germany's Reticence to Agree Threatens European Stability. Financial Times, June 24, http://www.georgesoros.com/articles-essays/entry/germanys_reticence_to_agree_ threatens_european_stability/

Swidlicki, P. - Kullmann, A. - Persson, M. (2012): Seizing the Moment: Aligning the EU Budget with Europe's Economic Needs. Open Europe, June, http://www.openeurope.org.uk/Content/ Documents/Pdfs/2012EUbudget.pdf

Vimont, P. (2016): Migration in Europe: Bridging the Solidarity Gap. Carnegie Europe, Brussels, September 12, http://carnegieendowment.org/files/Vimont_Migration_fulltext.pdf

Warleigh, A. (2002): Flexible Integration: Which Model for the European Union? London - New York: Sheffield Academic Press.

Wolff, G. B. (2012): A Budget Capacity for Europe's Monetary Union. Bruegel Policy Contribution, No. 2012/22, December, http://bruegel.org/wp-content/uploads/imported/publications/ pc_2012_22_EA_budget_final.pdf

Wolff, G. B. (2016): The Economic Consequences of Schengen. Bruegel blog, February 2, http:// bruegel.org/2016/02/the-economic-consequences-of-schengen/

Wyplosz, C. (2007): Has Europe Lost Its Heart? In: Åslund, A. - Dabrowski, M. (eds): Europe After Enlargement. Cambridge University Press, pp. 6-28.

Wyplosz, C. (2013): Europe's Quest for Fiscal Discipline. Economic Papers, No. 498, European Commission, Directorate-General for Economic and Financial Affairs, April

http://ec.europa.eu/economy_finance/publications/economic_paper/2013/pdf/ecp498_en.pdf

Wyplosz, C. (2015): The Centralization-Decentralization Issue. European Economy Discussion Paper, No. 014, September, ec.europa.eu/economy_finance/publications/eedp/pdf/dp014_en.pdf 